\title{
Influence of edaphic variables on the floristic composition and structure of the tree-shrub vegetation in typical and rocky outcrop cerrado areas in Serra Negra, Goiás State, Brazil ${ }^{1}$
}

\author{
MARIÂNGELA FERNANDES ABREU², JOSÉ ROBERTO RODRIGUES PINTO², \\ LEANDRO MARACAHIPES ${ }^{2}$, LETÍCIA GOMES ${ }^{2}$, EDMAR ALMEIDA DE OLIVEIRA ${ }^{2}$, \\ BEATRIZ SCHWANTES MARIMON², BEN HUR MARIMON JUNIOR², \\ JOSENILTON DE FARIAS ${ }^{4}$ and EDDIE LENZA ${ }^{2,5}$
}

(received: November 17, 2011; accepted: July 20, 2012)

\begin{abstract}
Influence of edaphic variables on the floristic composition and structure of the tree-shrub vegetation in typical and rocky outcrop cerrado areas in Serra Negra, Goiás State, Brazil). The present study analyzed the influence of edaphic variables on the floristic compositions and structures of the arboreal and shrub vegetation of typical cerrado (TC) and rocky outcrop cerrado (RC) communities in the Serra Negra mountain range in Piranhas Municipality, Goiás State, Brazil. Ten $20 \times 50 \mathrm{~m}$ plots were established in each community, and all individuals with minimum diameters $\geq 5 \mathrm{~cm}$ measured at $30 \mathrm{~cm}$ above soil level were sampled. Composite soil samples were collected at $0-20 \mathrm{~cm}$ depths in each plot for physical and chemical analyses. The proportions of above-ground rock cover work also estimated in each RC plot. A total of 2,009 individuals (83 species, 69 genera, and 34 families) were recorded. Qualea parviflora was the only species consistently among the 10 most structurally important taxa in both communities, and was considered a generalist species. The observed and estimated species richnesses were greater in RC than in TC, although plant basal areas and heights did not differ between them. There were positive correlations between rock cover $\times$ plant density and rock cover $\times$ basal areas. TWINSPAN and PCA analysis separated the TC and RC plots, and three RC habitat specialist species (Wunderlichia mirabilis, Norantea guianensis, and Tibouchina papyrus) were identified. Soil variables were found to have greater effects on the species compositions of the TC and RC sites than the geographic distances between sampling plots. According to CCA analysis, the exclusive (or more abundant species) of each community were correlated with soil variables, and these variables therefore determined the selection of some species and influenced the differentiation of the vegetation structures of the communities studied.
\end{abstract}

Key words - conservation, rocky outcrops, savanna, soils

\section{INTRODUCTION}

The occurrence of a plant species in a given environment is dependent on distinct factors acting at different spatial scales. The floristic composition and structure of the vegetation on local scales may be related to local topography and geomorphology (Motta et al. 2002), physicochemical properties of the soil (Reatto et al. 2008, Ribeiro \& Walter 2008), local fire history (Moreira 2000, Miranda et al. 2007),

1. Part of the master's dissertation of the first author, Programa de PósGraduação em Ecologia e Conservação, Universidade do Estado do Mato Grosso, Nova Xavantina, MT, Brazil.

2. Universidade do Estado de Mato Grosso, Programa de PósGraduação em Ecologia e Conservação, BR 158, km 655, Caixa Postal 08, 78 690-000 Nova Xavantina, MT, Brazil.

3. Universidade de Brasília, Programa de Pós-Graduação em Ciências Florestais, Caixa Postal 04337, 70 910-970 Brasília, DF, Brazil.

4. Rede de Biodiversidade e Biotecnologia da Amazônia Legal - Rede Bionorte/Unemat, BR 158, km 655, Caixa Postal 08, 78 690-000 Nova Xavantina, MT, Brazil.

5. Corresponding author: eddielenza@yahoo.com.br and/or anthropogenic disturbances (Ribeiro \& Walter 2008). The wide distribution of the Cerrado biome (approximately 2,000,000 $\mathrm{km}^{2}$ ) and its contact with the Amazon Forest, Atlantic Forest, Caatinga (dryland), and Pantanal (seasonally inundated) (Ribeiro \& Walter 2008) allow for ample floristic mixing at regional scales (Castro \& Martins 1999, Méio et al. 2003). Therefore, regional variations in climatic conditions (Silva et al. 2008) and altitudes (Motta et al. 2002), as well as the floristic influences of the biomes in direct contact with the Cerrado (Castro \& Martins 1999, Pinto \& Oliveira Filho 1999, Méio et al. 2003, Ratter et al. 2003, Bridgewater et al. 2004) act as determinates of regional species composition, favoring high richness.

According to Ribeiro \& Walter (2008), the Cerrado biome comprises forest, savanna, and campestre (open field) formations, with cerrado sensu stricto being characterized as a savanna formation composed of dense, typical, thin, and rocky outcrop cerrado physiognomies that are distinguishable based on their densities, heights, and tree-shrub covers. The principal 
determinants of these vegetation types are largely related to edaphic factors - especially the depth of the water table, drainage, the effective depth of the soil profile, the presence of concretions (Haridasan 2000), soil texture (Marimon Junior \& Haridasan 2005), and the percentage of exposed rock. Other environmental factors such as fire frequency also have a role in determining cerrado savanna typologies (Ribeiro \& Walter 2008).

Rocky outcrop cerrado is distinguishable from the other three cerrado physiognomies by the presence of many endemic habitat-specialist species (Romero \& Nakajima 1999, Simon \& Proença 2000, Pinto et al. 2009, Lima et al. 2010) that grow in areas of accentuated topography with many rock outcrops and shallow soils, where individual trees establish themselves in clefts in the rocks so that their densities will vary as a function of the specific conditions of each site (Ribeiro \& Walter 2008).

Comparative studies of the woody vegetation of rocky outcrop and typical cerrado sites can aid in evaluating the effects of edaphic conditions on their floristic compositions and structures. Floristic and phytosociological surveys are important vehicles for increasing our knowledge and understanding of the woody flora of rocky outcrop cerrado vegetation, especially in light of the fact that this phytophysiognomy has been well described (Ribeiro \& Walter 2008) but its community structure, spatial distribution, and interactions with the abiotic environment are not yet well understood. Rocky outcrop cerrado physiognomies have apparently been less impacted by anthropogenic activities as its stony nature makes crop cultivation nearly impossible (Machado et al. 2004). This situation increases the importance of floristic and structural analyses of the vegetation structure of rocky outcrop cerrado sites in elucidating interactions between vegetation formations and edaphic factors as well the role of this vegetation in maintaining the floral diversity of the Cerrado biome as a whole.

As such, the present study describes and compares the floristic compositions and structures of the tree-shrub vegetation of neighboring areas of typical cerrado and rocky outcrop cerrado vegetation, and evaluates the effects of distance and soil properties on the floristic composition at a local geographical scale in the Serra Negra Mountain Range, Goiás State, Brazil, in order to address the following hypotheses: 1 . That the floristic compositions and vegetation structures of typical cerrado and rocky outcrop cerrado are different; 2 . That soil characteristics influence the unique floristic compositions and vegetation structures of rocky outcrop cerrado and typical cerrado; 3 . That the densities and basal areas of tree-shrub individuals in rocky outcrop cerrado sites are inferior to those of typical cerrado.

\section{MATERIAL AND METHODS}

The present study was undertaken in the Serra Negra Mountain Range, in Piranhas Municipality, in the western mesoregion of Goiás State, Brazil $\left(16^{\circ} 25^{\prime} 37^{\prime \prime} \mathrm{S}\right.$ and $51^{\circ} 49^{\prime} 20^{\prime \prime} \mathrm{W}$ ). The regional climate is predominately type Aw according to the Köppen classification system, with two well-defined seasons: one dry and cold, and the other hot and humid; with an annual average precipitation rate of $1700 \mathrm{~mm}$, an annual average temperature of $25^{\circ} \mathrm{C}$, maximum and minimal annual average temperature of $32{ }^{\circ} \mathrm{C}$, and $18^{\circ} \mathrm{C}$, respectively (Silva et al. 2008).

The Serra Negra Range varies in altitude between 650 and $1000 \mathrm{~m}$ a.s.l. (Oliveira 2000) and extends between the cities of Piranhas and Baliza in Goiás State. It has a strongly contrasting topography of elevated peaks composed of rocks belonging to the Goiás Volcanic-Sedimentary Bom Jardim Complex of the Cuiabá and Granito Piranhas Group - part of the Goiás Magmatic Arc that formed during the Neoproterozoic era; the rocky outcrops are composed of approximately 500,000,000 year-old granites (Oliveira 2000).

The vegetation of the Serra Negra is composed of a mosaic of different cerrado physiognomies (sensu Ribeiro \& Walter 2008) with deciduous forests dominating on the steep slopes of the mountains, with high abundance of Attalea speciosa Mart. ex Spreng. (Arecaceae), and small natural areas of rocky outcrop cerrado. Narrow strands of non-flooding gallery forests are found in the valleys at the bases of the mountains. The tops of the mountains tend to be flat to undulating, and the typical cerrado there has largely been converted to pasture - leaving only small fragments of this original vegetation.

The study area was located $15 \mathrm{~km}$ from the town of Piranhas. We inventoried the trees and shrubs of the woody plant communities of typical cerrado (TC) ("cerrado típico" sensu Ribeiro \& Walter 2008) (16 $27^{\circ} 23^{\prime \prime}$ S and 51 ${ }^{\circ} 53^{\prime} 46^{\prime \prime} \mathrm{W}$; altitudes between 740 and $790 \mathrm{~m}$ ) and rocky outcrop cerrado (RC) ("cerrado rupestre" sensu Ribeiro \& Walter 2008) $\left(16^{\circ} 26^{\prime} 55^{\prime \prime} \mathrm{S}\right.$ and $51^{\circ} 53^{\prime} 58^{\prime \prime} \mathrm{W}$; altitudes between 760 and $810 \mathrm{~m}$ ); the two inventory sites were separated by $300 \mathrm{~m}$. We established ten $20 \times 50 \mathrm{~m}(0.1$ hectare $)$ plots separated by minimum distances of $50 \mathrm{~m}$ in both communities, totaling 2 ha, following the methodology described by Felfili et al. (2005)

Floristic and phytosociological surveys were undertaken in all plots, identifying to the species level all of trees, shrubs and monocotyledons individuals with minimum stem diameters $\geq 5 \mathrm{~cm}$ at $30 \mathrm{~cm}$ above soil level $\left(\mathrm{DB}_{30}\right)$. The circumferences of all living individuals (including monocotyledons) were measured at $30 \mathrm{~cm}$ above soil level, as well as their total heights. 
Plant identifications were made in the field whenever possible, or by subsequent consultation of the published literature and herbarium specimens held at the Nova Xavantina (NX) and Brasília University (UB) herbaria. The botanical classification followed APG III (2009) and the current nomenclature was confirmed using the Flora do Brasil electronic databank (Forzza et al. 2010). Reference samples of fertile individuals of all of the species collected were incorporated into the NX herbarium.

Soil samples were collected at depths of 0-20 cm, using a soil auger (Van Raij 1991), at three points (beginning, middle, and end) in each of the 10 plots in the TC and RC sites surveyed, totaling 20 samples. The soil samples were chemically analyzed by a commercial laboratory to determine their $\mathrm{pH}$, organic material content (OM), cationic exchange capacity (CEC), texture, and the concentrations of $\mathrm{P}, \mathrm{K}, \mathrm{Ca}$, $\mathrm{Mg}, \mathrm{S}, \mathrm{Na}, \mathrm{Al}, \mathrm{Fe}, \mathrm{Zn}, \mathrm{Mn}, \mathrm{Cu}$, and B, following Embrapa (1997) protocols. Total $\mathrm{N}$ concentrations were estimated by calculating $\mathrm{N}=\mathrm{OM} / 40$, according to Bezerra (2006). The percentage coverage of rock outcrops (or stones) in the rocky outcrop cerrado sites were visually estimated in each plot and classified into four categories: class 1 - from 0 to $25 \%$ rock cover; class 2 - from 26 to $50 \%$; class 3 - from 51 to $75 \%$; class 4 - from 76 to $100 \%$.

The EstimateS 8.0 software was used to estimate the accumulated species richnesses of the two communities using 10,000 randomizations and eight different estimators (ICE, Chao 1, Chao 2, Jack 1, Jack 2, Boostrap, MMRuns, and MMMeans) (Gotelli \& Colwell 2001, Colwell 2008). The best estimator was chosen based on analyses of the Spearman Correlations between the observed and estimated values of each area based on the maximum correlation value (Brose et al. 2003).

In order to characterize the phytosociological parameters of the plant communities examined we calculated the relative and absolute values of density, frequency, and dominance, which together yield the importance value (IV) (MuellerDombois \& Ellenberg 1974), using the Mata Nativa 2 software package (Cientec 2005).

Vegetation classification in the two study areas was undertaken using TWINSPAN (Two-Way Indicator Species Analysis) (Hill 1979) including all of the species sampled, with cutoff levels of 10, 15, 20, 25, and 30. Principal Component Analysis (PCA) was used to reduce the edaphic variables, using the PC-Ord program (McCune \& Mefford 1997). The principal matrix included all of the 20 chemical and physical soil variables $(\mathrm{Ca}, \mathrm{Mg}, \mathrm{Al}, \mathrm{H}+\mathrm{Al}, \mathrm{K}, \mathrm{P}$, organic material - OM, S, Na, Zn, B, Cu, Fe, Mn, cation exchange capacity - CEC, base saturation, aluminum saturation, clay, sand, and silt) while the secondary matrix considered the TC and RC plots. This procedure helped eliminate variables with low correlations and significance, resulting in the selection of nine principal edaphic variables (CEC, OM, $\mathrm{Mg}$, Ca, base saturation, aluminum saturation, sand, clay, and silt).

After selection, a second PCA was performed to correlate these edaphic variables with the plots of the communities sampled. Canonic Correspondence Analysis (CCA) was used to ordinate the edaphic variables with the vegetations of the $\mathrm{TC}$ and $\mathrm{RC}$ communities, with the principal matrix being composed of species with 10 or more individuals in at least one community (totaling 39 species), the secondary matrix used the nine edaphic variables selected by PCA.

The Mantel Partial test was used to examine the effects of the edaphic variables and the distances between the sites on species composition, using species abundance as the principal matrix and the edaphic variables and the distances between the plots as secondary matrices, using NTSYS 2.1 software (Rohlf 2000). Environmental data expressed in varying units were standardized to comparable equivalences and weights, and the positions of the plots were expressed in metric units (UTM coordinates).

Spearman Correlation analyses were performed only for the rocky outcrop cerrado sites, in terms of their different estimated exposed rock covers per plot, considering the densities of the individuals, their basal areas, and median heights. The median diameters $\left(\mathrm{DB}_{30}\right)$, heights, and densities between the two communities were compared using the Mann-Whitney test (U). This same test was also used to evaluate the differences between the edaphic variables of the two sites. These analyses were undertaken using BioStat 5.0 software (Ayres et al. 2007). A 5\% level of significance was adopted in all of the statistical analyses.

\section{RESULTS}

A total of 2009 individuals were encountered in the two vegetation communities, representing 83 species, 69 genera, and 34 families (table 1). Twenty-two species occurred only in typical cerrado (TC) and 23 only in rocky outcrop cerrado (RC); 38 species were common to both communities. Fifty-eight species, 51 genera, and 31 families were encountered in the TC, while 61 species, 51 genera, and 27 families were encountered in the RC. The estimated species richness of the TC using the Mao Tau method, when compared to the abundance of 931 individuals in the $\mathrm{RC}$, was $56.33 \pm 1.85$, which was less than the number of species recorded in the RC. The correlation analyses indicated that Bootstrap was the best species estimator as it estimated 63.24 species in the $\mathrm{TC}$ site and 67.34 species in the RC, with a correlation value of $r=0.999$ with the numbers of species observed in the two communities.

Three species were most highly represented in the TC interms of numbers ofindividuals: Byrsonima pachyphylla (174 ind ha-1), Qualea parviflora (121 ind ha ${ }^{-1}$ ), and Davilla elliptica (91 ind ha $\left.{ }^{-1}\right)$, which represented approximately $16 \%, 11 \%$ and $8 \%$ of the community respectively. The three most abundant species in the 


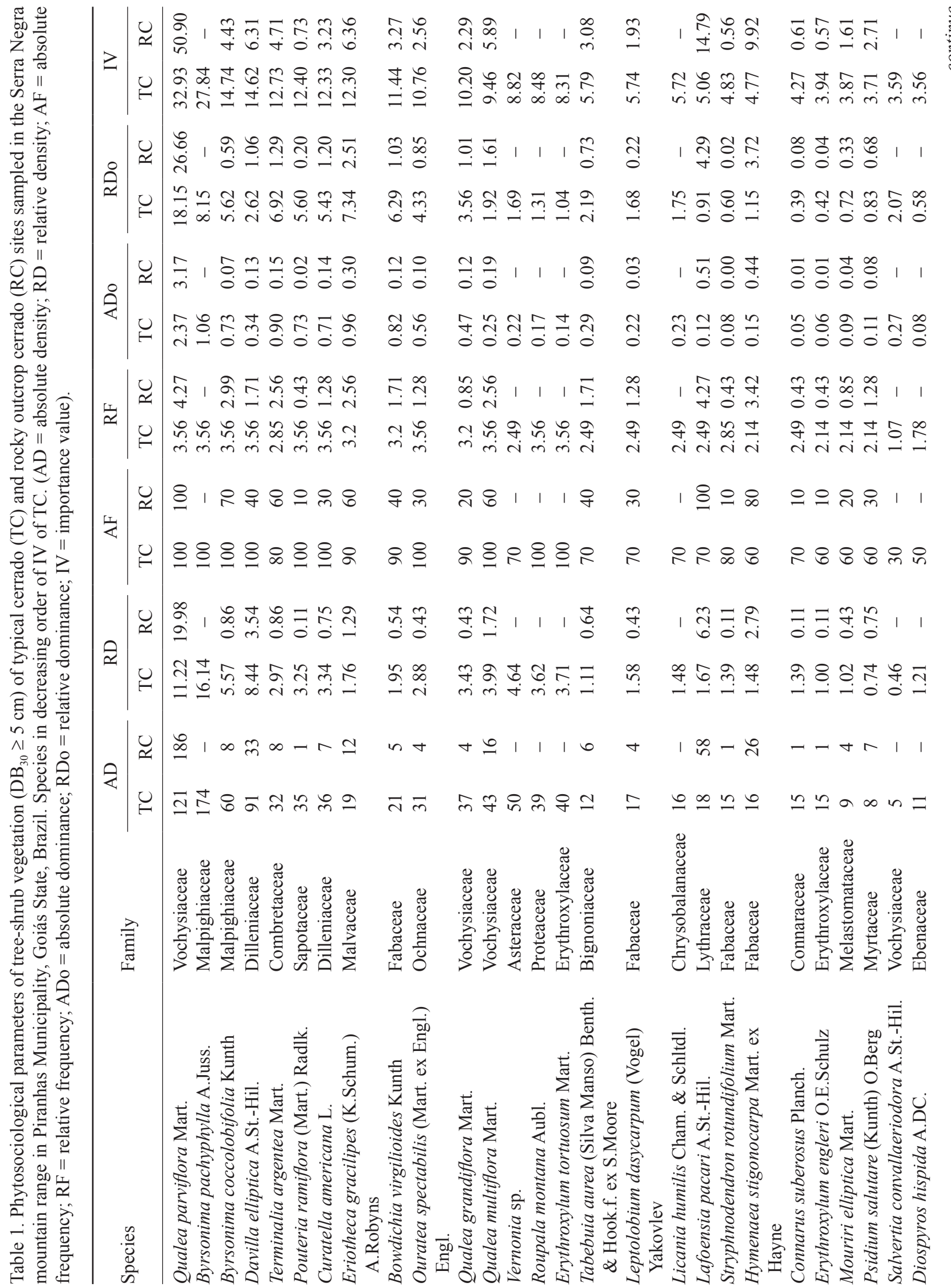




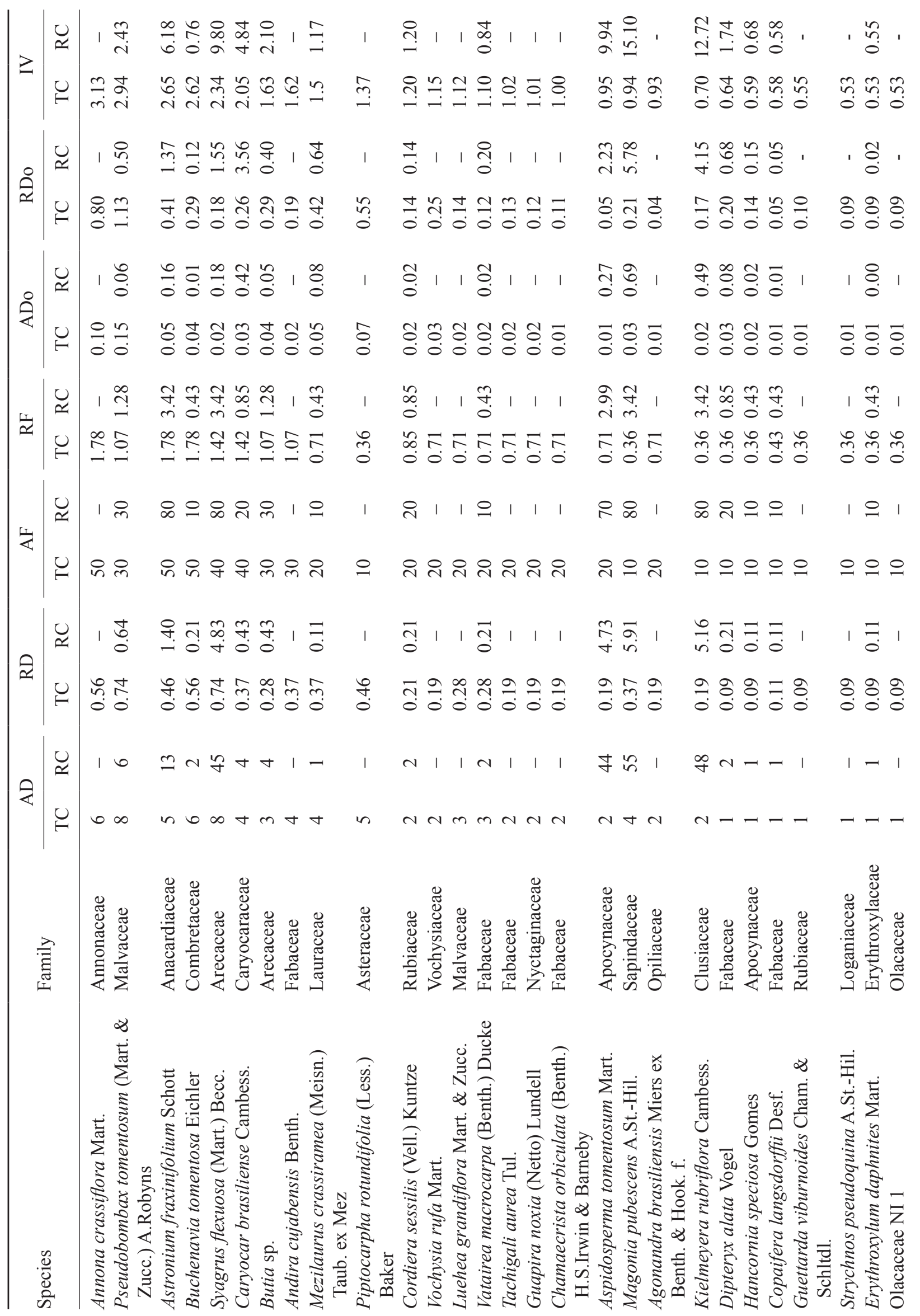




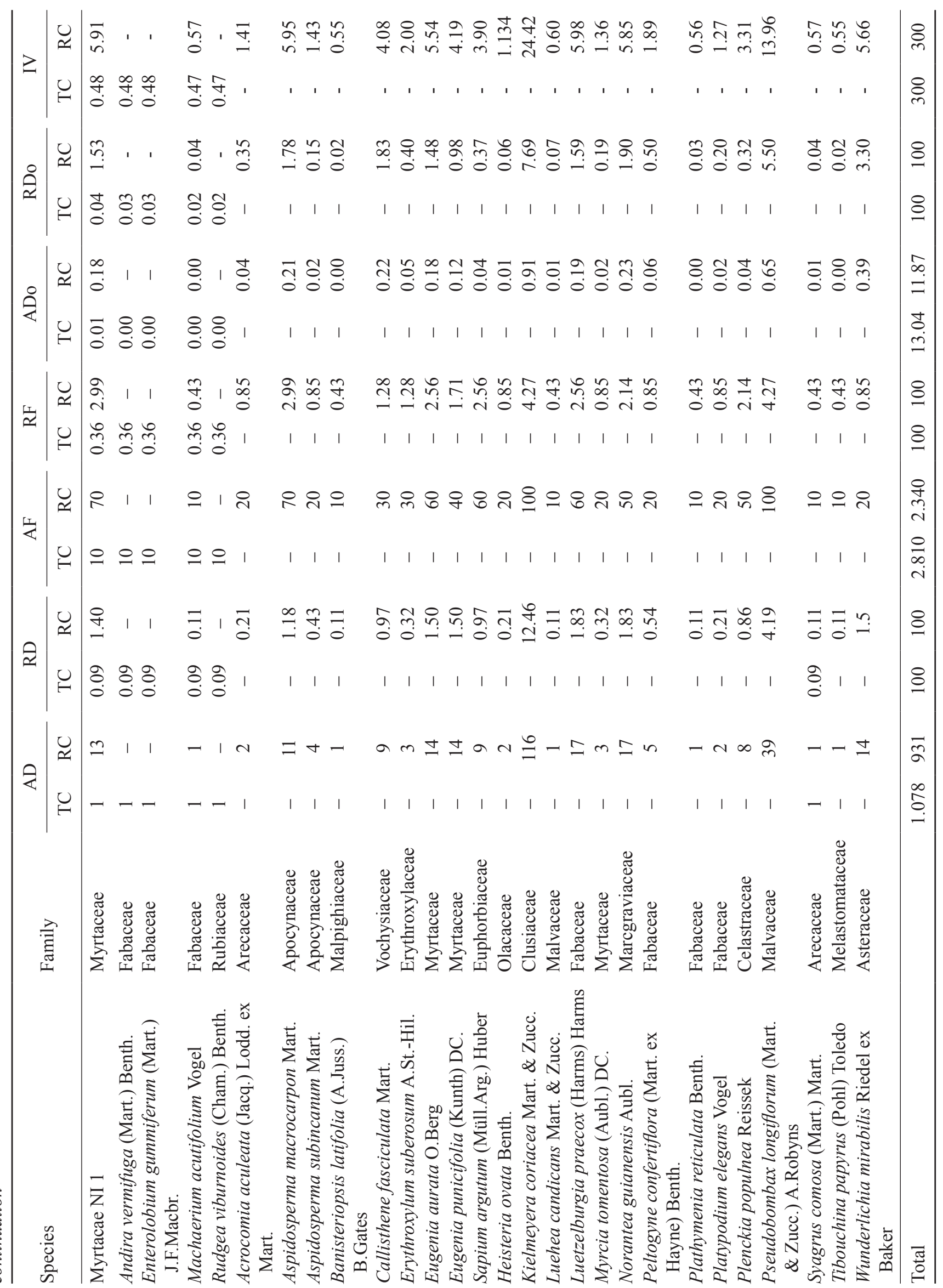


RC were: Qualea parviflora (186 ind ha $\left.{ }^{-1}\right)$, Kielmeyera coriacea $\left(116\right.$ ind $\left.^{-1} \mathrm{a}^{-1}\right)$, and Lafoensiapacari (58 ind ha $\left.\mathrm{h}^{-1}\right)$, which represented approximately $20 \%, 12 \%$, and $6 \%$ of the community respectively (table 1).

The densities of live individuals in the $10 \mathrm{TC}$ and RC plots were 1078 ind ha-1 and 931 ind ha ${ }^{-1}$ respectively, while the total basal areas of live individuals were $13.04 \mathrm{~m}^{2} \mathrm{ha}^{-1}$ in TC, and $11.7 \mathrm{~m}^{2} \mathrm{ha}^{-1}$ in RC. The densities of live individuals per plot were significantly higher in the TC $(\mathrm{U}=5.27 ; P=0.0001)$, although there were no differences between the basal areas per plot between TC and RC sites $(\mathrm{U}=1.436 ; P=0.9069)$. The greatest concentrations of live individuals in the TC and RC sites were between the height classes of 2.1 and $4.0 \mathrm{~m}$, reinforcing the tree-shrub characters of these two woody communities. The average heights in the TC and $\mathrm{RC}$ sites (3.7 and $3.8 \mathrm{~m}$ respectively) were similar $(\mathrm{U}=1.52 ; P=0.1278)$, while the average diameter of the individuals in the TC sites $(9.2 \mathrm{~cm})$ was lesser than that found in the $\mathrm{RC}(10.1 \mathrm{~cm})(\mathrm{U}=4.60 ; P=0.0001)$. The percentage rock exposition in the RC was positively related to plant density $\left(\mathrm{r}^{2}=0.2991 ; P=0.0025\right)$ and basal area $\left(\mathrm{r}^{2}=0.3127 ; P=0.0015\right)$, but no relationship was identified between percentage rock exposition and the heights of individuals per plot $\left(\mathrm{r}^{2}=0.0547\right.$; $P=0.5887$ ).

The 10 species with the greatest Importance Value (IV) in the TC accounted for approximately $54 \%$ of the total IV, $70 \%$ of the total basal area, and $57 \%$ of the total density, while the 10 species with the greatest IV in the RC contributed to $56 \%$ of the IV, $64 \%$ of the total basal area, and $67 \%$ of the density (table 1 ). Of the 10 most important species in the two areas, Qualea parviflora demonstrated the largest relative values of density, dominance, and frequency - which guaranteed it the greatest IV in the two areas. Species such as Wunderlichia mirabilis, Tibouchina papyrus, Norantea guianensis, Kielmeyera coriacea, and Pseudobombax longiflorum were recorded only in RC, while Byrsonima pachyphylla, Roupala montana, Erythroxylum tortuosum and Vernonia sp. occurred only in TC.

TWINSPAN classification consistently separated the TC and RC plots in the first division (eigenvalue of 0.56), with only two RC plots (RC2 and RC7) being grouped with those of TC (figure 1). Byrsonima pachyphylla was considered as the indicator species of TC, as it only occurred in that community. Davilla elliptica, Qualea grandiflora, and Vernonia sp. demonstrated consistently higher numbers of individuals in TC. Kielmeyera coriacea was considered as the indicator species of RC, while Aspidosperma

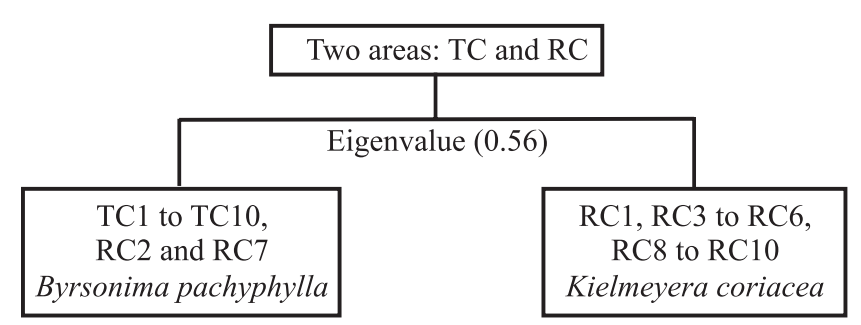

Figure 1. TWINSPAN classifications of 20 sampling plots of the typical cerrado (TC1 to TC10) and rocky outcrop cerrado (RC1 to RC10) in the Serra Negra mountain range in Piranhas Municipality, Goiás State, Brazil.

tomentosum, Qualea parviflora, Magonia pubescens, Syagrus flexuosa, and Kielmeyera rubriflora were considered as the preferential.

Based on field observations and on the physical analyses of the soils (table 2), the TC site was found to have well-drained Red-Yellow Latosols with large quantities of clay and silt. The soils at the RC site were identified as Sandy Shallow Neosols on granitic outcrops. The superficial layer of the RC soil was dark, indicating the presence of organic material in the substrates occurring in the rock fissures. The soils of both communities had loam-clay-sandy textures (sensu Embrapa 2006), were dystrophic, acidic, and allic, had low CECs and base saturations and high concentrations of exchangeable potassium (table 2). There were significant differences between the two areas in terms of their concentrations of $\mathrm{H}+\mathrm{Al}, \mathrm{K}, \mathrm{P}, \mathrm{OM}, \mathrm{N}$, and $\mathrm{Na}$, and in terms of soil texture, with the greatest mineral concentrations found in the RC site (table 2).

Phosphorus availability was considered low in both areas, with values between 0.1 and $1.8 \mathrm{mg} \mathrm{dm}^{-3}$; $\mathrm{K}$ values were $93 \mathrm{mg} \mathrm{dm}^{-3}$ in the TC and $115 \mathrm{mg} \mathrm{dm}^{-3}$ in the RC. All of the soil samples demonstrated elevated acidity, with $\mathrm{pH}$ values between 3.8 and 4.3 (Malavolta 1992). The RC site had high OM contents, especially in plots 5,7 and 8 (with values of $54 \mathrm{~g} \mathrm{dm}^{-3}$ ) (Bezerra 2006). In general, $\mathrm{Ca}$ and $\mathrm{Mg}$ varied from low to moderate in the TC and RC sites respectively. High Al saturation values were observed in both TC $(38.2 \%)$ and RC (48.7\%) sites, with low base saturations in both communities (table 2 ). In relation to the micronutrients, $\mathrm{B}, \mathrm{Zn}$ and $\mathrm{Cu}$ showed low concentrations, while $\mathrm{Fe}$ and $\mathrm{Mn}$ concentrations were very high in both areas (Malavolta 1992).

The concentrations of the macronutrients N, P and $\mathrm{K}$ were always greater in RC. No significant differences were noted between the micronutrient concentrations in the two phytophysiognomies examined, or differences between their CECs and base saturations. The clay 
Table 2. Comparisons of the physical and chemical characteristics of the soils $(0-20 \mathrm{~cm}$ depth) of typical cerrado (TC) and rocky outcrop cerrado $(\mathrm{RC})$ areas in the Serra Negra mountain range in Piranhas Municipality, Goiás State, Brazil. Results of $P$ in bold type represent significant differences $(<0.05)$ between the areas by the Mann-Whitney test $(\mathrm{U})$. $(\mathrm{OM}=$ organic material; $\mathrm{CEC}=$ cation exchange capacity).

\begin{tabular}{|c|c|c|c|c|c|c|c|c|}
\hline \multirow{2}{*}{ Properties } & \multicolumn{3}{|c|}{$\mathrm{TC}$} & \multicolumn{3}{|c|}{$\mathrm{RC}$} & \multirow{2}{*}{$\mathrm{U}$} & \multirow{2}{*}{$P$} \\
\hline & Maximum & Minimum & Average & Maximum & Minimum & Average & & \\
\hline $\mathrm{Ca}\left(\mathrm{cmol}_{\mathrm{c}} \mathrm{dm}^{-3}\right)$ & 1.50 & 0.40 & 0.65 & 1.00 & 0.10 & 0.45 & 1.81 & 0.06 \\
\hline $\operatorname{Mg}\left(\mathrm{cmol}_{\mathrm{c}} \mathrm{dm}^{-3}\right)$ & 0.90 & 0.30 & 0.35 & 0.60 & 0.10 & 0.30 & 1.47 & 0.14 \\
\hline $\mathrm{Al}\left(\mathrm{cmol}_{\mathrm{c}} \mathrm{dm}^{-3}\right)$ & 1.00 & 0.50 & 0.80 & 1.20 & 0.80 & 0.90 & 1.47 & 0.14 \\
\hline $\mathrm{H}+\mathrm{Al}\left(\mathrm{cmol}_{\mathrm{c}} \mathrm{dm}^{-3}\right)$ & 8.90 & 5.30 & 6.70 & 10.10 & 7.20 & 8.15 & 2.45 & 0.01 \\
\hline $\mathrm{K}\left(\mathrm{mg} \mathrm{dm} \mathrm{m}^{-3}\right)$ & 115.00 & 81.00 & 93.00 & 128.00 & 95.00 & 115.00 & 3.02 & $<<0.01$ \\
\hline $\mathrm{P}\left(\mathrm{mg} \mathrm{dm}^{-3}\right)$ & 0.30 & 0.10 & 0.20 & 4.00 & 0.10 & 0.50 & 2.04 & 0.04 \\
\hline $\mathrm{OM}\left(\mathrm{g} \mathrm{dm}^{-3}\right)$ & 54.00 & 31.00 & 38.00 & 54.00 & 35.00 & 48.00 & 2.34 & 0.01 \\
\hline $\mathrm{N}(40 \%)\left(\mathrm{g} \mathrm{dm}^{-3}\right)$ & 1.35 & 0.77 & 0.95 & 1.35 & 0.87 & 1.20 & 2.34 & 0.01 \\
\hline $\mathrm{S}\left(\mathrm{mg} \mathrm{dm}^{-3}\right)$ & 7.10 & 3.40 & 5.60 & 8.7 & 2.80 & 4.20 & 1.22 & 0.22 \\
\hline $\mathrm{Na}\left(\mathrm{mg} \mathrm{dm}^{-3}\right)$ & 6.00 & 4.00 & 5.00 & 7.00 & 5.00 & 6.00 & 2.34 & 0.01 \\
\hline $\mathrm{Zn}\left(\mathrm{mg} \mathrm{dm}^{-3}\right)$ & 1.80 & 0.40 & 0.50 & 0.80 & 0.40 & 0.70 & 1.36 & 0.17 \\
\hline $\mathrm{B}\left(\mathrm{mg} \mathrm{dm}^{-3}\right)$ & 0.17 & 0.12 & 0.15 & 0.17 & 0.12 & 0.15 & 0.49 & 0.62 \\
\hline $\mathrm{Cu}\left(\mathrm{mg} \mathrm{dm}^{-3}\right)$ & 0.70 & 0.40 & 0.50 & 0.60 & 0.30 & 0.50 & 1.28 & 0.19 \\
\hline $\mathrm{Fe}\left(\mathrm{mg} \mathrm{dm}^{-3}\right)$ & 125.90 & 81.90 & 90.15 & 116.20 & 72.10 & 91.55 & 0.03 & 0.96 \\
\hline $\operatorname{Mn}\left(\mathrm{mg} \mathrm{dm}^{-3}\right)$ & 56.40 & 31.70 & 42.80 & 52.20 & 20.10 & 36.70 & 1.28 & 0.19 \\
\hline $\mathrm{CEC}$ & 9.94 & 6.86 & 8.32 & 11.51 & 8.10 & 9.03 & 1.81 & 0.06 \\
\hline Base Sat. (V\%) & 31.88 & 10.48 & 13.99 & 19.87 & 6.41 & 11.40 & 1.73 & 0.08 \\
\hline Al Sat. $(\mathrm{m} \%)$ & 52.08 & 15.67 & 38.20 & 67.07 & 28.23 & 48.70 & 1.51 & 0.13 \\
\hline $\mathrm{pH} / \mathrm{CaCl}_{2}$ & 4.30 & 3.80 & 3.90 & 4.00 & 3.80 & 3.90 & 0.64 & 0.52 \\
\hline Clay $\left(\mathrm{g} \mathrm{kg}^{-1}\right)$ & 370.00 & 300.00 & 345.00 & 320.00 & 300.00 & 300.00 & 3.17 & $<<0.01$ \\
\hline Silt $\left(\mathrm{g} \mathrm{kg}^{-1}\right)$ & 100.00 & 80.00 & 90.00 & 90.00 & 80.00 & 80.00 & 2.38 & 0.01 \\
\hline Sand $\left(\mathrm{g} \mathrm{kg}^{-1}\right)$ & 620.00 & 540.00 & 560.00 & 620.00 & 590.00 & 620.00 & 3.17 & 0.00 \\
\hline
\end{tabular}

content of the TC soil was greater than that of the RC substrate (table 2).

The TC and RC plots were separated by Principal Component Analysis (PCA), with the variance percentage of axis 1 being $44.33 \%$ and axis 2 being $28.34 \%$; both axes together explained $72.68 \%$ of the accumulated variance (figure 2). In general, axis 1 was associated with soil chemical variables, while axis 2 reflected their physical variables. The TC plots, located in the lower left of the diagram, were related to larger concentrations of the micronutrients $\mathrm{Ca}$ and $\mathrm{Mg}$, greater base saturations, and higher concentrations of clay and silt. The RC plots, located in the upper right of the diagram, were related to sites with higher aluminum saturation, and higher concentrations of organic material, CEC, and sand.

Soil properties had greater influence on species composition of the TC and RC sites $(r=0.27886$; $P=0.0016)$ than did the distances between the plots ( $\mathrm{r}=0.14510 ; P=0.0463)$ as determined by Mantel Partial Analysis. Canonic Correspondence Analysis (CCA) demonstrated a separation of the plant species of the TC and RC communities, corroborating the previous analyses (figures 1, 2 and 3). The variance percentages explained by the CCA axes (figure 3 ) were 33 and 5.8\% for axis 1 and 2 respectively. The Pearson Correlations were significant for both axis $1(\mathrm{r}=0.932)$ and axis 2 $(r=0.875)$. In general, edaphic variables were better correlated with axis 1 , while only the variables $\mathrm{OM}$ and Al were better correlated with axis 2. The Monte Carlo permutation test yielded a value of $P=0.005$, indicating that the species-variables relationships of the two axes were significant.

Species that demonstrated positive and significant correlations with the right side of axis 1 in the CCA (figure 3), such as Norantea guianensis and Wunderlichia mirabilis, were exclusive to or most abundant in RC and were associated with greater values of sand, aluminum saturation, OM, and CEC. The species on the left side of axis 1 of the CCA were exclusive to or most abundant in TC, such as Byrsonima pachyphylla, Roupala montana, and Davilla elliptica, and were associated with greater values of clay, silt, base saturations, $\mathrm{Ca}$, and $\mathrm{Mg}$. 


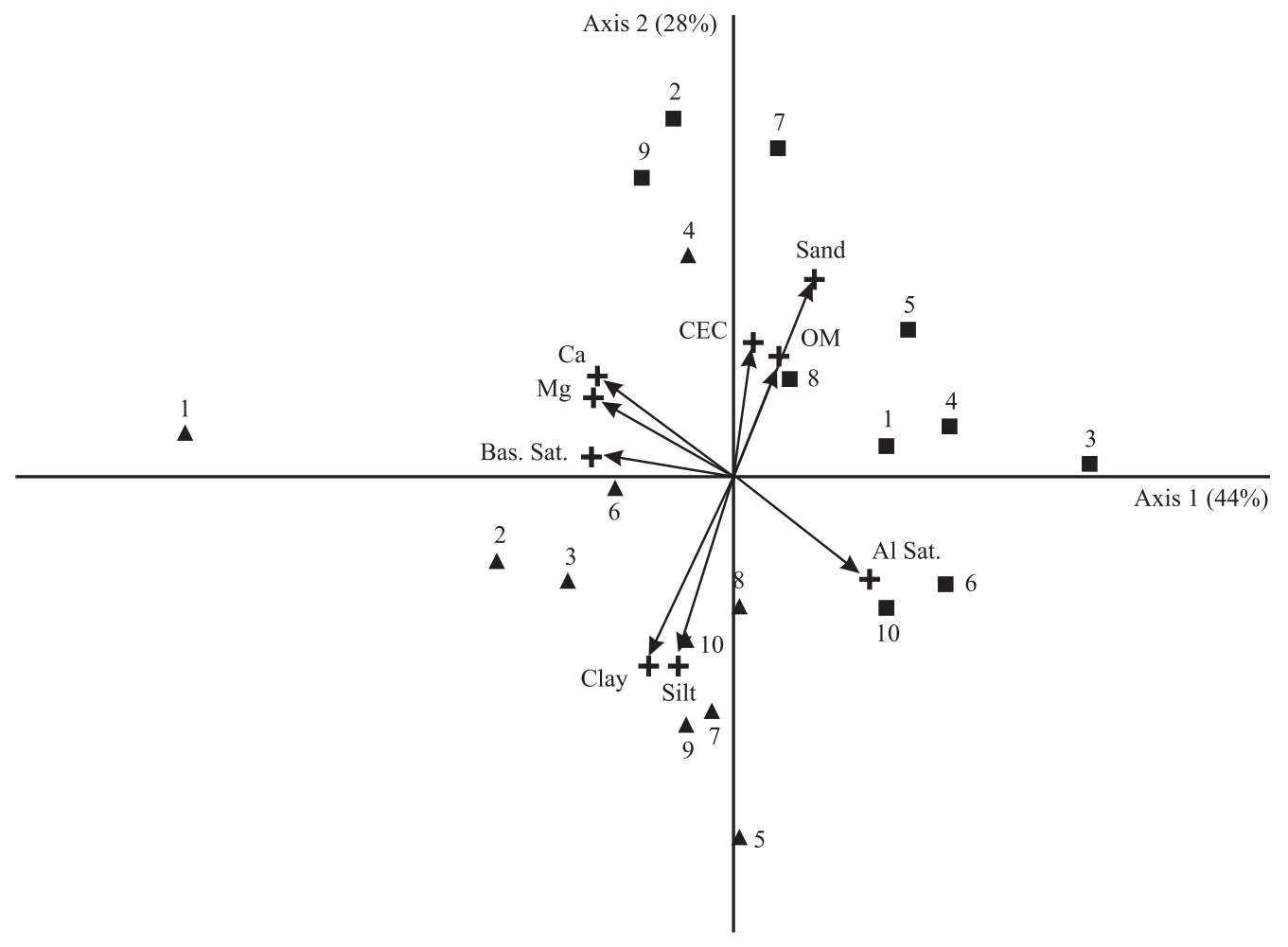

Figure 2. Principal Components Analysis (PCA) of the attributes of the 10 plots $(20 \times 50 \mathrm{~m})$ established in typical cerrado $(\boldsymbol{\Lambda})$ and 10 plots in rocky outcrop cerrado (घ) and their physicochemical soil variables $(+)$ in the Serra Negra mountain range in Piranhas Municipality, Goiás State, Brazil.

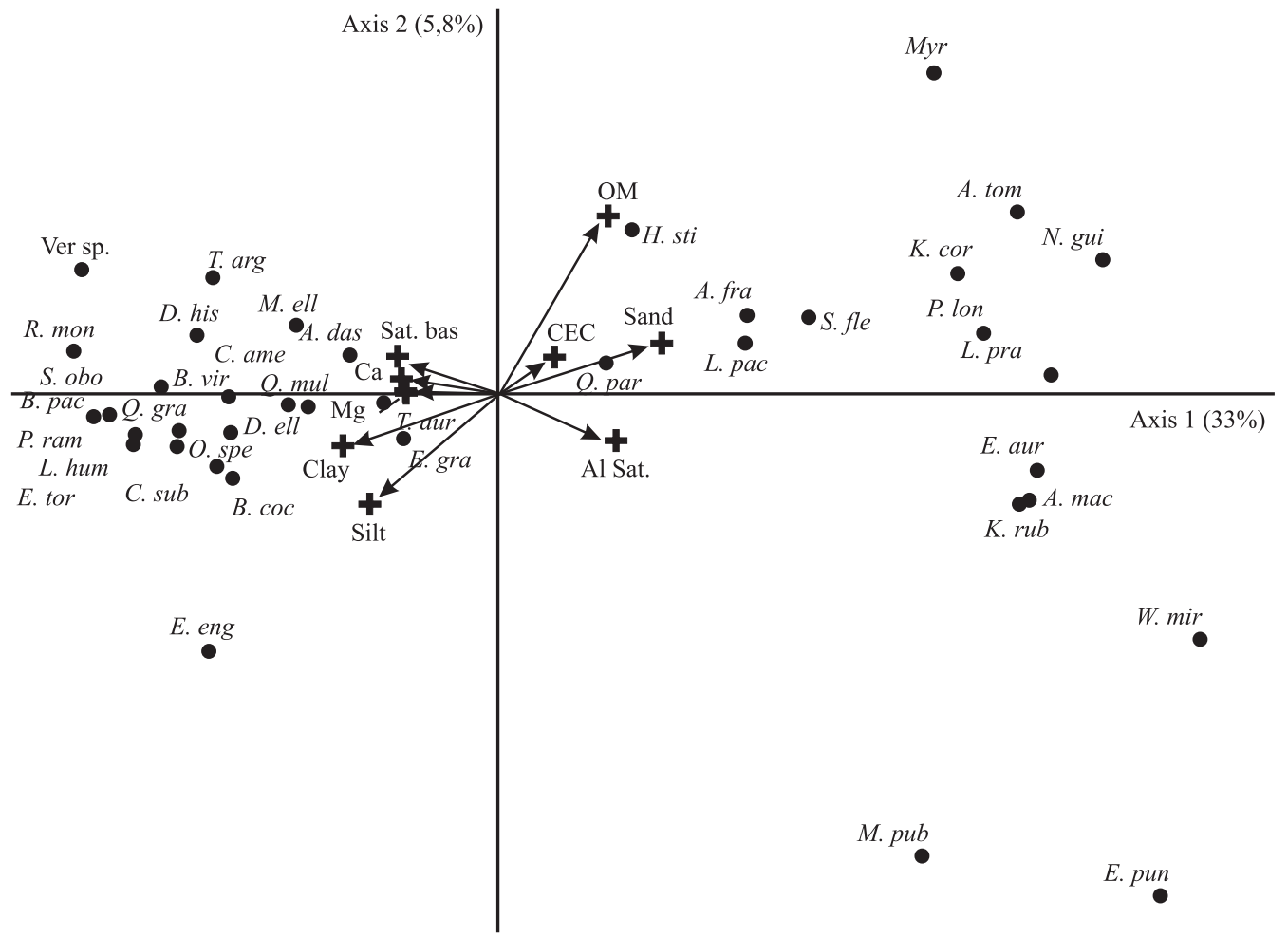

Figure 3. Ordination diagram of Canonical Correspondence Analysis (CCA) of the densities of $39(\bullet)$ common species $(n \geq 10$ individuals) of typical cerrado (TC) and rocky outcrop cerrado (RC) and (+) edaphic variables in the Serra Negra Mountain Range in Piranhas Municipality, Goiás State, Brazil. 


\section{DISCUSSION}

Tree-shrub cerrado savanna formations growing on rocky substrates might be expected to have reduced plant densities (Ribeiro \& Walter 2008) - which could limit species richness. However, both the recorded and estimated (Bootstrap) species richnesses of RC were greater than those of TC in the present study, and similar studies undertaken in rocky outcrop cerrado areas in central Brazil corroborate this similarity in species richness between the two formations (Pinto et al. 2009, Lima et al. 2010, Moura et al. 2010, Maracahipes et al. 2011, Gomes et al. 2011). Hypothesis 1, that RC areas should be more restrictive to the establishment of plant species because of their rock outcrops and shallow soils, was not corroborated in the present study or by other studies undertaken in the Cerrado biome (Pinto et al. 2009, Lima et al. 2010, Gomes et al. 2011). As such, it can be concluded that the shallow substrate and uneven topography of rocky outcrop cerrado sites are not determinate factors of local richness or alpha-diversity (Felfili \& Felfili 2001, Moura et al. 2010).

The fact that the densities of live individuals in TC were observed to be greater than those of RC indicates that the inclined topography and the rocky and shallow RC substrate are determinate factors limiting the establishment of individuals (Ribeiro \& Walter 2008). In spite of the lower densities of plants in the RC, the basal area values and average heights of those individuals did not differ between TC and RC sites. Additionally, the diameter values in the $\mathrm{RC}$ areas were greater than those seen in TC sites, indicating that in spite of the lower densities of individuals in the RC studied here their development and biomass accumulations were significant greater. As such, species established in areas with rock outcrops appear to possess appropriate colonization strategies and are adapted to surviving in rocky crevices, those successfully occupying the few sites available to them (Ribeiro \& Walter 2008). Other authors have likewise noted the capacity of certain species to develop in shallow rocky soils, resulting in woody communities that are structurally similar to those observed on deep soils (Silva et al. 2002, Pinto et al. 2009, Moura et al. 2010, Lima et al. 2010, Gomes et al. 2011). Individuals of some woody cerrado species that occur in rocky outcrop cerrado areas demonstrate more premature, intense, and prolonged deciduousness during the dry season than individuals of the same species growing in typical cerrado sites on deep soils (Silvério \& Lenza 2010). As such, we can infer that one of the strategies of plants growing on soils with reduced capacities for water retention (as in the case of rocky outcrop cerrado) is the plasticity of their phenological events - which serve to reduce water losses and maximize water use during the dry season.

Other indications of the success of individuals growing on rocky RC soils included significant positive relationships between the percentages of rock cover (rock cover classes) and plant density, and between rock cover and basal area; no significant relation was detected between rock cover and plant height. These results contradicted hypothesis 3 - that the densities and basal areas of tree-shrub individuals in rocky outcrop cerrado areas would be inferior to those values in typical cerrado sites. As such, the micro-sites available in RC areas studied apparently offer adequate conditions for the establishment and successful development of woody individuals. It also appears that the rocky substrate of the rocky outcrop cerrado promotes greater micro-habitat heterogeneity and therefore provides greater varieties of sites adequate to the establishment of different species - explaining the elevated richness values observed.

The high representivity of just a few species in terms of their numbers of individuals and their importance values, as seen in the present study, is often observed in woody savanna communities of typical cerrado (Felfili \& Silva Júnior 1993, Cardoso et al. 2002, Campos et al. 2006) and rocky outcrop cerrado (Amaral et al. 2006, Viana \& Lombardi 2007, Lima et al. 2010). There were, however, marked differences between the 10 most important species in the two cerrado communities, with only Qualea parviflora being of marked structural importance in both TC and RC sites. Other studies have likewise demonstrated significant differences between the most important species (in terms of vegetation structure) in typical cerrado and rocky outcrop cerrado areas (Pinto et al. 2009, Lima et al. 2010, Lenza et al. 2011, Gomes et al. 2011). Thus, although the TC and $\mathrm{RC}$ areas shared considerable numbers of species $(n=38$ species, $34.48 \%$ of the species of TC and $37.70 \%$ of the species of RC), they were still significantly different in terms of the species that dominated each community.

The high numbers of species and individuals of the genus Qualea and their high representivity suggests that the taxa of this genus are well-adapted to different substrates and are therefore widely distributed in the Cerrado biome (Ratter et al. 2003). Qualea parviflora demonstrated the largest IV in the RC, confirming a pattern observed in previous phytosociological studies of cerrado savanna formations (Nogueira et al. 2001, Felfili et al. 2002, Balduino et al. 2005, Amaral et al. 2006, Felfili \& Fagg 2007, Miranda et al. 2007, Pinto et al. 
2009). This taxon was considered a generalist species by Ratter et al. (2000), and has been reported in many areas throughout the Cerrado biome.

Rocky outcrop cerrado areas have generally been described as having high numbers of habitat-specialist species among herbaceous-subshrub plants (Pirani et al. 1994, Harley 1995, Romero \& Martins 2002, Conceição \& Pirani 2007) as well as in the tree-shrub layer (Simon \& Proença 2000). The edaphic characteristics and climatic conditions of rupestral environments appear to favor the occurrence of rare, endemic, and habitat-specialist species (Pirani et al. 1994, Romero \& Nakajima 1999, Simon \& Proença 2000). Only three habitat-specialist species were encountered in the rocky outcrop cerrado (Tibouchina papyrus, Wunderlichia mirabilis and Norantea guianensis) in the present study, as was also reported by Amaral (2006), Pinto et al. (2009), and Ribeiro \& Walter (2008), suggesting that the RC areas studied have peculiar flora.

The floristic and structural peculiarities of the TC and $\mathrm{RC}$ were confirmed by classification (TWINSPAN) and ordination (PCA) analyses that separated the two areas in consistent and significant manners according to their edaphic variables - corroborating our hypothesis that soil properties significantly influence the floristic and structural differences between rocky outcrop cerrado and typical cerrado sites. A study undertaken by Gomes et al. (2011) that compared adjacent areas of typical cerrado and rocky outcrop cerrado near Nova Xavantina, MT, demonstrated the formation of groups of plots from TC and RC areas using DCA - Detrended Correspondence Analysis. As such, certain soil properties must be acting at local scales in differential manners in the two communities. The floristic and structural results presented here reinforce the classification system of Cerrado physiognomies proposed by Ribeiro \& Walter (2008) that is principally based on edaphic properties.

The chemical properties of RC soils may facilitate or maintain species growth as they contain significant quantities of the macronutrients $\mathrm{N}, \mathrm{P}, \mathrm{K}$ and $\mathrm{S}$ as well as organic material. It is known that rock crevices can accumulate organic material and, consequently, nutrients needed for plant growth and development (Benites et al. 2007).

It therefore appears that distinct physical-chemical soil properties, with greater proportions of clay and micronutrients in TC areas and sandier RC soils with higher levels of OM and macronutrients are responsible for the floristic and structural differences of these two vegetation communities. A number of studies have shown that edaphic factors, such as soil fertility and its physical composition, can influence local floristic compositions and species distributions (Ratter \& Dargie 1992, Haridasan 2000, Oliveira Filho \& Ratter 2002, Moura et al. 2010). Marimon Junior \& Haridasan (2005), for example, reported large differences in the floristic compositions of two areas of typical cerrado and cerradão (arboreal cerrado) that were more closely related to soil texture than to any other factor. The thin soils of rocky outcrop cerrado areas and their highly sandy texture may limit the establishment and development of certain arboreal species, and these physical impediments to rooting may represent (together with the chemical attributes of the soils) a strong factor in species selection.

The results of the Mantel Partial Test consolidated the observation that the physical-chemical properties of the soils better explained the structural differences in the vegetation of the TC and $\mathrm{RC}$ areas than the distances between them - thus reinforcing hypothesis 2 (that the soil strongly influences floristic and structural differences between TC and RC). This hypothesis was also supported by the PCA analyses that demonstrated a relationship between RC plots and sandy soils with high levels of organic material and high aluminum saturation, while TC plots were more associated with finer soil textures (more clay and silt), greater base saturation, and higher concentrations of $\mathrm{Ca}$ and $\mathrm{Mg}$. In specific terms, the CCA and TWINSPAN analyses indicated the separation of the vegetations of RC and TC sites. Among the species associated with RC by CCA were Wunderlichia mirabilis and Norantea guianensis - which are either habitat-specialists or endemic to rupestral environments (Paxisto 1985, Riberio \& Walter 2008, Oliveira Filho \& Fluminhan Filho 1999).

Species such as Byrsonima pachyphylla, Roupala montana, and Davilla elliptica were associated with TC soils, indicating their preferences for deeper substrates. These species have been cited as being abundant in areas of typical cerrado (Balduino et al. 2005, Marimon Junior \& Haridasan 2005, Gomes et al. 2011) but generally do not occur (or are only found at very low densities) in rocky outcrop cerrado sites (Pinto et al. 2009, Lima et al. 2010, Moura et al. 2010, Lenza et al. 2011, Gomes et al. 2011). Thus, while generalist species such as Qualea parviflora can be found in both areas, there appears to be a selection for species more highly adapted to thin soils (such as $W$. mirabilis and $N$. guianensis) in RC sites and for species less tolerant to shallow soils (such as $R$. montana and B. pachyphylla) in TC sites.

Our results indicate that the rocky soils of RC areas do not restrict species richness or the establishment 
and development of woody individuals, but rather act to select for habitat-specialist species that prefer rocky soil and will dominate the community structure. Local factors, however, such as soils that have higher clay contents and higher concentrations of micronutrients in TC areas or sandy soils with high levels of OM and macronutrients in $\mathrm{RC}$ areas, may strongly influence the structural differentiation observed between rocky outcrop cerrado and typical cerrado areas.

Acknowledgments - The authors thank Prof. Dr. Guilherme Bossi Buck for his help in interpreting the soil fertility parameters; Capes/Fapemat for awarding a Masters grant to the first author; the Fundação Grupo Boticário de Proteção à Natureza and Procad/Capes (no 109/2007) for their financial support.

\section{REFERENCES}

Amaral AG, Pereira FFO, Munhoz CBR. 2006. Fitossociologia de uma área de cerrado rupestre na Fazenda Sucupira, Brasília-DF. Cerne 12:350-359.

APG III. 2009. An update of the Angiosperm Phylogeny Group classification for the orders and families of flowering plants: APG III. Botanical Journal of the Linnean Society 161:105-121.

Ayres M, Ayres LD, Santos AAS. 2007. BioEstat 5 - Aplicações estatísticas nas áreas das ciências Biomédicas. Universidade Federal do Pará, Belém.

Balduino APC, Souza AL, Meira Neto JAA, Silva AF, Silva Júnior MC. 2005. Fitossociologia e análise comparativa da composição florística do cerrado da flora de Paraopeba-MG. Revista Árvore 29:25-34.

Benites VM, Schaefer CEGR, Simas FNB, Santos HG. 2007. Soils associated with rock outcrops in the Brazilian mountain ranges Mantiqueira and Espinhaço. Revista Brasileira de Botânica 30:569-577.

Bezerra JF. 2006. Solo: substrato da vida. Embrapa Recursos Genéticos e Biotecnologia, Brasília.

Bridgewater S, Ratter JA, Ribeiro JF. 2004. Biogeographic patterns, $\beta$ diversity and dominance in the cerrado biome of Brazil. Biodiversity and Conservation 13:2295-2318.

Brose U, Martinez ND, Williams RJ. 2003. Estimating species richness: sensitivity to sample coverage and insensitivity to spatial patterns. Ecology 84:2364-2377.

Campos EP, Duarte TG, Néri AV, Silva AF, Meira Neto JAA, Valente GE. 2006. Composição florística de um trecho de cerradão e cerrado sensu stricto e sua relação com o solo na Floresta Nacional (Flona) de Paraopeba, MG, Brasil. Revista Árvore 30:471-479.

Cardoso E, Moreno MIC, Guimarães AJM. 2002. Estudo fitossociológico em área de cerrado sensu stricto na Estação de Pesquisa e Desenvolvimento Ambiental Galheiro Perdizes, MG. Caminhos de Geografia 3:30-43.
Castro AAJF, Martins FR. 1999. Cerrados do Brasil e do Nordeste: caracterização, área de ocupação e considerações sobre a sua fitodiversidade. Pesquisa em Foco 7:147-178.

Cientec - Consultoria e Desenvolvimento de Sistemas. 2005. Mata Nativa 2. Manual do usuário. Cientec, Viçosa.

Colwell RK. 2008. EstimateS: Statistical estimation of species richness and shared species from samples. Version 8.0. http://www.purl.oclc.org/estimates (accessed 2011 Feb 2).

Conceição AB, Pirani JR. 2007. Diversidade em quatro áreas de campos rupestres na chapada Diamantina, Bahia, Brasil: espécies distintas, mas riquezas similares. Rodriguésia 58:193-206.

Embrapa. 1997. Manual de métodos de análise de solo. 2 ed. Centro Nacional de Pesquisa de solos, Rio de Janeiro.

Embrapa. 2006. Sistema brasileiro de classificação de solos. Embrapa Solos, Rio de Janeiro.

Felfili JM, Silva Júnior MC. 1993. A comparative study of cerrado (sensu stricto) vegetation in Central Brazil. Journal of Tropical Ecology 9:277-289.

Felfili MC, Felfili JM. 2001. Diversidade alfa e beta no cerrado sensu stricto da Chapada Pratinha, Brasil. Acta Botanica Brasilica 15:243-254.

Felfili JM, Nogueira PE, Silva Júnior MC, Marimon BS, Delitti WBC. 2002. Composição florística e fitossociológica do cerrado sentido restrito no município de Água Boa-MT. Acta Botanica Brasilica 16:103-112.

Felfili JM, Carvalho FA, Haidar RF. 2005. Manual para o monitoramento de parcelas permanentes nos biomas Cerrado e Pantanal. Editora UnB, Brasília.

Felfili JM, Fagg CW. 2007. Floristic composition. diversity and structure of the "cerrado" sensu stricto on rocky soils in northern Goiás and southern Tocantins, Brazil. Revista Brasileira de Botânica 30:375-385.

Forzza RC, Leitman PM, Costa AF, Carvalho JR, AA, Peixoto AL, Walter BMT, Bicudo C, Zappi D, Costa DP, Lleras E, Martinelli G, Lima HC, Prado J, Stehmann JR, Baumgratz JFA, Pirani JR, Sylvestre L, Maia LC, Lohmann LG, Queiroz LP, Silveira M, Coelho MN, Mamede MC, Bastos MNC, Morim MP, Barbosa MR, Menezes M, Hopkins M, Secco R, Cavalcanti TB, Souza VC. 2010. Lista de espécies da flora do Brasil. Jardim Botânico do Rio de Janeiro. http://floradobrasil.jbrj.gov. br/2010/ (acessed 2011 Mar 22).

Gomes L, Lenza E, Maracahipes L, Marimon BS, Oliveira EA. 2011. Comparações florísticas e estruturais entre duas comunidades lenhosas de cerrado típico e cerrado rupestre, Mato Grosso, Brasil. Acta Botanica Brasilica 25:866-876.

Gotelli NJ, Colwell RK. 2001. Quantifying biodiversity: procedures and pitfalls in the measurement and comparison of species richness. Ecology Letters 4:379391.

Haridasan M. 2000. Nutrição mineral de plantas nativas do cerrado. Revista Brasileira de Fisiologia Vegetal 12:54-64. 
Harley RM. 1995. Introdução. In Flora of the Pico das Almas Chapada Diamantina - Bahia, Brazil (BL Stannard, ed.). Royal Botanical Gardens, Kew, p.43-78.

Hill MO. 1979. TWINSPAN - Fortran program for arranging multivariate data in an ordered two way table by classification of the individuals and the attributes. Cornell University, Ithaca.

Lenza E, Pinto JRR, Pinto AS, Maracahipes L, Bruziguessi EP. 2011. Comparação da vegetação arbustivo-arbórea de uma área de cerrado rupestre na Chapada dos Veadeiros, Goiás, e áreas de cerrado sentido restrito do Bioma Cerrado. Revista Brasileira de Botânica 34:247-259.

Lima TA, Pinto JRR, Lenza E, Pinto AS. 2010. Florística e estrutura da vegetação arbustiva-arbórea em uma área de cerrado rupestre no Parque Estadual de Caldas Novas, Goiás. Biota Neotropica 10:159-166.

Machado RB, Ramos Neto MB, Pereira PGP, Caldas EF, Gonçalves DA, Santos NS, Tabor K, Steininger M. 2004. Estimativas de perda da área do Cerrado brasileiro. Conservação Internacional, Brasília.

Malavolta E. 1992. ABC da análise de solos e folhas. Editora Agronômica Ceres, São Paulo.

Maracahipes L, Lenza E, Marimon BS, Oliveira EA, Pinto JRR, Marimon Junior BH. 2011. Estrutura e composição florística da vegetação lenhosa em cerrado rupestre na transição Cerrado-Floresta Amazônica. Biota Neotropica 11:134-141.

Marimon Junior BH, Haridasan M. 2005. Comparação da vegetação arbórea e características edáficas de um cerradão e um cerrado sensu stricto em áreas adjacentes sobre solo distrófico no leste de Mato Grosso, Brasil. Acta Botanica Brasilica 19:913-926.

Mccune B, Mefford MJ. 1997. PC-ORD. Multivariate analysis of ecological data, version 3.17. MjM Software, Oregon.

Méio BB, Freitas CV, Jatobá L, Silva MEF, Ribeiro JF, Henriques RPB. 2003. Influência da flora das florestas Amazônica e Atlântica na vegetação do cerrado sensu stricto. Revista Brasileira de Botânica 26:437-444.

Miranda SC, Silva Júnior MC, Salles LA. 2007. A comunidade lenhosa do cerrado rupestre na Serra Dourada, Goiás. Heringeriana 1:43-53.

Moreira AG. 2000. Effects of fire protection on savanna structure in central Brazil. Journal of Biogeography 27:1021-1029.

Motta PEF, Carvalho Filho A, Ker JC, Pereira NR, Carvalho JW, Blancaneaux P. 2002. Relações solo-superfície geomórfica e evolução da paisagem em uma área do Planalto Central Brasileiro. Pesquisa Agropecuária Brasileira 37:869-878.

Moura IO, Gomes-Klein VL, Felfili JM, Ferreira HD. 2010. Diversidade e estrutura comunitária de cerrado sensu stricto em afloramentos rochosos no Parque Estadual dos Pireneus, Pirenópolis, Goiás. Revista Brasileira de Botânica 33:455-467.
Mueller-Dombois D, Ellenberg H. 1974. Aims and methods of vegetation ecology. John Wiley and Sons, New York.

Nogueira PE, Felfili JM, Silva Júnior MC. 2001. Composição florística e fitossociologia do cerrado sentido restrito no município de Canarana-MT. Boletim do Herbário Ezechias Paulo Heringer 8:28-43.

Oliveira IWB. 2000. Cobre do Bom Jardim Estado de Goiás. Companhia de Pesquisa de Recursos Minerais, Goiânia.

Oliveira Filho AT, Fluminhan Filho M. 1999. Ecologia da vegetação do Parque Florestal Quedas do Rio Bonito. Cerne 5:51-64.

Oliveira Filho AT, Ratter JA. 2002. Vegetation physionomies and woody flora of the cerrado biome. In The cerrados of Brazil (PS Oliveira, RJ Marquis, eds.). Columbia University Press, New York, p.91-120.

PeixotoABF. 1985. Flora do Estado de Goiás: Marcgraviaceae. Editora da Universidade Federal de Goiás, Goiânia.

Pinto JRR, Oliveira Filho AT. 1999. Perfil florístico e estrutura da comunidade arbórea de uma floresta de vale no Parque Nacional da Chapada dos Guimarães, Mato Grosso, Brasil. Revista Brasileira de Botânica 22:53-67.

Pinto JRR, Lenza E, Pinto AS. 2009. Composição florística e estrutura da vegetação arbustiva-arbórea em um cerrado rupestre, Cocalzinho de Goiás, Goiás. Revista Brasileira de Botânica 32:23-32.

Pirani JR, Giulietti AM, Mello-Silva R. 1994. Checklist and patterns of geographic distribution of the vegetation of Serra do Ambrósio, Minas Gerais, Brazil. Revista Brasileira de Botânica 17:133-147.

Ratter JA, Dargie TCD. 1992. An analysis of the floristic composition of 26 cerrado areas in Brazil. Edinburgh Journal of Botany 49:235-250.

Ratter JA, Bridgewater S, Ribeiro JF, Dias TAB, Silva MR. 2000. Estudo preliminar da distribuição das espécies lenhosas da fitofisionomia cerrado sentido restrito nos estados compreendidos pelo bioma Cerrado. Boletim Herbário Ezechias Paulo Heringer 5:5-43.

Ratter JA, Bridgewater S, Ribeiro JF. 2003. Analysis of the floristic composition of the Brazilian cerrado vegetation III: comparison of the woody vegetation of 376 areas. Edinburgh Journal of Botany 60:57-109.

Reatto A, Correia JR, Spera ST. 2008. Solos do Bioma do Cerrado: aspectos pedológicos. In Cerrado: ecologia e flora (SM Sano, SP Almeida, JF Ribeiro, eds.). EmbrapaCPAC, Planaltina, p.107-149.

Ribeiro JF, Walter BMT. 2008. As principais fitofisionomias do Bioma Cerrado. In Cerrado: ecologia e flora (SM Sano, SP Almeida, JF Ribeiro, eds.). Embrapa-CPAC, Planaltina, p.151-212.

Rohlf FJ. 2000. NTSYS-pc: numerical taxonomy and multivariate analysis system. Applied Biostatistics, New York. 
Romero R, Nakajima JN. 1999. Espécies endêmicas do Parque Nacional da Serra da Canastra. Revista Brasileira de Botânica 22:259-265.

Romero R, Martins A. 2002. Melastomataceae do Parque Nacional da Serra da Canastra, Minas Gerais, Brasil. Revista Brasileira de Botânica 25:19-24.

Silva FAM, Assad ED, Evangelista BA. 2008. Caracterização climática do Bioma Cerrado. In Cerrado: ecologia e flora (SM Sano, SP Almeida, JF Ribeiro, eds.). EmbrapaCPAD, Planaltina, p.71-88.

Silva LO, Costa DA, Espírito Santo Filho K, Ferreira HD, Brandão D. 2002. Levantamento florístico e fitossociológico em duas áreas de Cerrado sensu stricto no Parque Estadual da Serra de Caldas Novas. Goiás. Acta Botanica Brasilica 16:43-53.
Silvério DV, Lenza E. 2010. Fenologia de espécies lenhosas em um cerrado típico no Parque Municipal do Bacaba, Nova Xavantina, Mato Grosso, Brasil. Biota Neotropica 10:205-216.

Simon MF, Proença C. 2000. Phytogeographic patterns of Mimosa (Mimosoideae, Leguminosae) in the Cerrado biome of Brazil: an indicator genus of high altitude center of endemism? Biological Conservation 96:279296.

Van Raij B. 1991. Fertilidade do solo e adubação. Editora Agronômica Ceres, São Paulo.

Viana PL, Lombardi JA. 2007. Florística e caracterização dos campos rupestres sobre canga na Serra da Calçada, Minas Gerais, Brasil. Rodriguésia 58: 159-177. 